\section{Kastamonu Eğitim Dergisi Kastamonu Education Journal}

Temmuz 2019 Cilt:27 Sayı:4

kefdergi.kastamonu.edu.tr
Başvuru Tarihi/Received: 26.07.2018

Kabul Tarihi/Accepted: 17.10 .2018 DOI: $10.24106 /$ kefdergi.3241

\title{
8. Sınıf Öğrencilerinin Matematiksel Problemler Bağlamındaki Argümantasyon Süreçlerinin İncelenmesi
}

\section{The Examination of the Argumentation Processes of $8^{\text {th }}$ Grade Students in the Context of Mathematical Problems}

\section{Öz}

\author{
Sare ŞENGÜL ${ }^{1}$, Sevilay TAVŞAN ${ }^{2}$
}

Bu araştırmanın amacı 8. sınıf öğrencilerinin matematiksel problemler bağlamındaki argümantasyon süreçlerinin incelenmesidir. Çalışma Trabzon ilinde bir devlet ortaokulunda gerçekleştirilmiştir. Çalışma grubu, "benzeşik (homojen) örnekleme" yöntemi ile seçilen üç öğrenciden oluşmaktadır. Bu öğrencilerin ikisi kız, biri erkektir. Araştırmada, nitel araştırma modellerinden biri olan özel durum çalışması kullanılmıştı. Veri toplama aracı olarak iki problem çözme etkinliği, yarı yapılandırımış görüşme formu, video ve ses kayıt cihazları kullanılmıştır. Problem çözüm süreçlerinde, öğrenciler arasında meydana gelen tartışmalar Toulmin'in argümantasyon modeline göre analiz edilmiştir. Öğrencilerin sürece yönelik görüşlerini incelemek için ise Akı ve Gürel'in (2016) çalışmalarında kullanmış oldukları çerçeveden yararlanılmıştır. Araştırma sonucunda öğrencilerin argümantasyon bileşenlerinden en çok iddia (94), en az ise destekleyici (0) bileşenini kullandıkları tespit edilmiştir. Öğrencilerin ikinci uygulama sürecinde oluşturdukları argüman sayısının birinciye göre daha fazla olduğu belirlenmiştir. Bununla birlikte öğrencilerin grupça tartş̧arak problem çözme sürecinin kendilerine bilişsel, duyuşsal, sosyal paylaşım ve dilsel bileşenler bağlamında katkı sağladığı yönünde açıklamalarda bulundukları görülmüştür.

Anahtar Kelimeler: argümantasyon, toulmin modeli, problem çözme

\section{Abstract}

The aim of research is to examine of argumentation process of 8th grade students in the context of mathematical problems. The study was conducted in a state secondary school in the province of Trabzon. The study group consists of three students selected by the "homogeneous sampling" method. Two of these students are girls and one is a boy. Case study, one of the qualitative research, was used in this study. Two problem solving activities, semi-structured interview form, video and audio recorders were used as data collection tools. Discussions that occured between students in the process of problem solving were analyzed according to Toulmin's argumentation model. Also, in order to examine the opinions of students on the process was benefited framework that Akı and Gurel (2016) used in their studies. As a result of the research, it has been determined that the students used the most claim (94) and at least the backing (0) component in the argumentation components. It has been determined that the number of arguments that students created during the second implementation process was higher than the first. In addition to this, it has been seen that students explained that solve problems by group discussing have contributed to them in the context of cognitive, affective, social sharing and linguistic components.

Keywords: argumentation, toulmin's model, problem solving

1. Marmara Üniversitesi, Atatürk Eğitim Fakültesi Illköğretim Bölümü Matematik Öğretmenliği Ana B.D., i̇stanbul, Türkiye; https://orcid.org/0000-0002-1069-9084. 2. Marmara Üniversitesi Doktora Öğrencisi, İstanbul, Türkiye; https://orcid.org/0000-0002-0400-3140,

Attf / Citation: Şengül, S., \& Tavşan, S. (2019). 8. Sınıf öğrencilerinin matematiksel problemler bağlamındaki argümantasyon süreçlerinin incelenmesi. Kastamonu Education Journal, 27(4), 1679-1693. doi:10.24106/kefdergi.3241 


\section{Extended Abstract}

Introduction: Secondary 5-8. classes mathematics curricula aim to educate students who question and construct mathematical knowledge as well as consider learning as an effective process. The Ministry of National Education (Mone, 2018) stated that this aim in their curricula as "to be in logical conclusions and inferences" and "to defend the validity and validity of the conclusions". In this context, it is important design enviroments that students to think critically and put forward justifications, to present alternative solutions and to allow them to share their ideas easily (Akdur and Kurbanoglu, 2014). It can be said that inquiry-based studies may provide opportunities for students to develop these skills.

The first studies on how the concept of argumentation, which is one of the inquiry-based approaches, should be applied methodologically in learning environments was done by Toulmin (1958). According to Toulmin (1958), the building block of "argumentation" constitutes six different arguments: claim, data, warrant, backing, qualitative and rebuttal. Claim expresses the ideas that one wants to convince the other. Data indicates the truths, facts and information on which the claim is based. Warrant is an expression describing the relationship between claims and data (Driver, Newton ve Osborne, 2000). Backing is an explanation that increasing the acceptability of a warrant. Rebuttal is the expression of the conditions under which the claim is not valid. Qualifier (limiter) indicates that under what conditions the claim is valid (Sanchez and Uriza, 2008).

Some of the researchers have defined the argumentation as a process in which strategies are created to solve a problem (Garcia-Mila and Andersen, 2008; Jimenez-Aleixandre, Rodriguez and Duschl, 2000; Miller, 1987). However, some researchers have considered the argumentation as a reasoning process in which students with different opinions are trying to persuade each other by advocating their own arguments in an environment where they interact with each other (Andriessen, Baker and Suthers, 2003; Keogh and Naylor, 2007; Puvirajah, 2007). Based on all this, it can be said that the argumentation is a process, accordingly teachers and students take various roles in order to organize this process well in the learning environments. In this process, teachers have roles such as revealing students' prior knowledge, to participate in the process and to provide continuity by asking questions to the students. In this context, also the students are expected to make claims by observing and giving instructions, to create evidence to support these claims, to reach the conclusion by participating in discussions and interpret the data (Keys, Hand, Prain and Collins, 1999).

Inglis, Mejia-Ramos and Simpson (2007) emphasize that the mathematical problem solving of students should take place in the context of the argumentation process from a young age. Because, in this process, the students can look for a solution the cause and effect by interpreting together, and they have the opportunity to think and inquire deeply about what is said because they interact with each other (Sekercci, 2013). In addition, the process of argumentation helps learners to see their own deficiencies (Akpınar and Ergin, 2005) as well as reveal their thoughts about a subject and contribute to the development of discussion skills (Toulmin, 1958). In other words, it can be said that the argumentation process has many advantages in terms of the students, it enables that to create a discussion environment in the problem solving process and students to reach the solution by making inquiries. When the studies reached in the context of secondary school students were examined, no studies were conducted to elaborate the students' argumentation processes during problem solving. It is considered that qualitative studies that examine this process in detail are needed in order to better see the students' argumentation processes during problem solving. Examining the process of argumentation in the context of problem solving can help both teachers and students because this process enables that students gain experience, to complete their deficiencies, and to be trained as individuals who can solve their problems in the future. Starting from these, in this study the process of argumentation of 8th grade students in the context of mathematical problems is examined.

Method: Case study, one of the qualitative research, was used in this study. The study group consists of three students selected by the "homogeneous sampling" method. In the elections of students, the averages of the three mathematics exams in the first semester of the 2016-2017 academic year, including the TEOG score, the teachers' opinions and the voluntary principle were adopted. The average of the students is between $90-100$ and three students have been identified by their teachers considering the fact that they have ability such as understanding what they read, commenting, expressing feelings and thoughts, and offering alternative solutions. Two of these students are girls and one is a boy. Two problem solving activities, semi-structured interview form, video and audio recorders were used as data collection tools. Discussions that occured between students in the process of problem solving were analyzed according to Toulmin's argumentation model in context of understanding of the problem, planning, plan implementation and evaluation phases. In the study, the question component was used in addition to the six components of the Toulmin model. Also, in order to examine the opinions of students on the process was benefited framework that Akı and Gurel (2016) used in their studies.

Results: As a result of the research, it has been determined that the students used the most claim (94) and at least the backing $(0)$ component in the argumentation components. The frequency of use of the components between the claim and the backing is in the form of data (14), question (6), warrant (5), rebuttal (1). According to the findings of the research, it has been seen that the number of arguments that students created during the second implementation process was higher than the first. In addition to this, it has been seen that students explained that solve problems by group discussing have contributed to them in the context of cognitive, affective, social sharing and linguistic components. Also, students stated that the interrogations carried out in the process add different cognitive experiences to them. Moreover, they indicated that the application process was enjoyable and that they were happy to be with their friends in the context of the affective component. In particular, they emphasized that social sharing occured in group was accelerated the problem solving process. And then, students has expressed their opinion within the context of linguistic experience by stating that they can understand their thoughts more easily to students who are in the same level with themselves. 


\section{Giriş}

Ortaokul 5-8. sınıflar matematik dersi öğretim programları öğrenmeyi etkin bir süreç olarak ele almanın yanı sıra matematiksel bilgiyi sorgulayan ve yapılandıran öğrenciler yetiştirmeyi amaçlamaktadır. Milli Eğitim Bakanlığı (MEB, 2018) bu amacını öğretim programlarında "Mantıklı genellemelerde ve çıkarımlarda bulunma" ve "çıkarımların doğruluğunu ve geçerliğini savunma" şeklinde belirtmiştir. Bu bağlamda öğrencilerin eleştirel düşünüp gerekçeler ortaya koymalarına, alternatif çözüm yolları sunmalarına ve fikirlerini rahatlıkla paylaşmalarına imkân verebilecek ortamların oluşturulması önem taşımaktadır (Akdur ve Kurbanoğlu, 2014). Sorgulamaya dayalı çalışmaların öğrencilerin belirtilen bu becerilerinin gelişimine firsat sunabileceği söylenebilir.

Sorgulamaya dayanan yaklaşımlardan biri olan argümantasyon kavramının öğrenme ortamlarında metodolojik olarak nasıl uygulanması gerektiği hakkında ilk çalışmalar Toulmin (1958) tarafindan yapılmıştır. Toulmin'e (1958) göre "argümantasyon"un yapı taşını iddia, veri, gerekçe, destekleyici, niteleyici ve çürütücü (reddedici) olmak üzere alt farklı argüman oluşturmaktadır. İddia; sözlü veya yazılı olarak savunulan görüşü, diğer bir deyişle kişinin karşısındakini ikna etmek istediği fikirleri ifade etmektedir. Veri; iddianın dayandığı ve iddiaları destekleyen doğruları, bilgileri, gerçekleri belirtmektedir. Gerekçe; iddia ve veri arasındaki ilişkiyi açıklayan ifadeleri kast etmektedir (Driver, Newton ve Osborne, 2000). Destekleyici, bir gerekçeyi destekleyen ve kabul edilebilirliğini artırmaya yönelik olan açıklamalardır. Çürütücü, iddianın geçerli olmadığı koşulları ortaya koyan ifadelerdir. Niteleyici (sınırlayıcı) ise, iddianın hangi koşullar altında geçerli olduğunu, diğer bir deyişle kesinlik derecesini bildirmektedir (Sanchez ve Uriza, 2008).

Araştırmacıların bazıları argümantasyonu, karşılaşılan bir problemi çözebilmek amacıyla stratejilerin oluşturulduğu bir süreç olarak tanımlamışlardır (Garcia-Mila ve Andersen, 2008; Jimenez-Aleixandre, Rodriguez ve Duschl, 2000; Miller, 1987). Örneğin, Miller (1987) argümantasyonu, öğrencilerin bir problem için çözüm öne sürme girişimleri ile süreç içerisinde meydana gelen akıl yürütmelerinin koordinasyonu şeklinde tanımlamıştır. Jimenez-Aleixandre, Rodriguez ve Duschl (2000) argümantasyonu karşılaşılan problemleri çözebilmek için kullanılan yöntemler olarak ele almıştr. Garcia-Mila ve Andersen (2008) argümantasyonu problemlerin mantıkı bir şekilde çözülmesini amaçlayan bir süreç şeklinde ifade etmiştir. Bazı araştırmacılar ise argümantasyonu, farklı fikirde olan öğrencilerin birbirleriyle etkileşim halinde oldukları bir ortamda kendi iddialarını savunarak birbirlerini ikna etmeye çalıştkları bir akıl yürütme süreci olarak ele almışlardır (Andriessen, Baker ve Suthers, 2003; Keogh ve Naylor, 2007; Puvirajah, 2007). Örneğin; Andriessen, Baker ve Suthers (2003) argümantasyonu problem için farklı görüşler ortaya koymak, belirtilen görüşlerin nedenlerini belirtmek, farklı görüşte olanları ikna etmeye çalışmak şeklinde açıklamıştır. Puvirajah (2007) argümantasyonu problem çözüm sürecinde ortaya çıkan akıl yürütme süreci olarak ifade ederken; Keogh ve Naylor’a (2007) öğrencilerin farklı fikirler ortaya koyduğu, çeşitli kanıtlar ve akıl yürütmeler ile bu fikirleri savunduğu bir süreç olarak tanımlamaya çalışmıştr. Belirtilen açıklamalar doğrultusunda, argümantasyonun bir süreci ifade ettiği, dolayısıyla öğrenme ortamlarında bu sürecin iyi bir şekilde organize edilebilmesinde öğretmen ve öğrencilere çeşitli roller düştüğü söylenebilir. Bu süreçte öğretmenlerin "öğrencilerin ön bilgilerini ortaya çıkarma, sürece katılımcı olma ve öğrencilere yönlendirici sorular sorarak sürecin devamını sağlama" gibi rolleri bulunmaktadır. Buna karşılık öğrencilerin ise "gözlem ve verilerden yola çıkarak iddialar oluşturmaları, bu iddiaları destekleyecek kanıt oluşturmaları, yapılan tartışmalara katılarak verileri yorumlayıp sonuca ulaşmaları" beklenmektedir (Keys, Hand, Prain ve Collins, 1999, s.2719).

Alan yazını incelendiğinde matematik bağlamında argümantasyon ile ilgili yapılmış çeşitli çalışmalara ulaşılmıştır. Ulaşılan bu çalışmalardan bazılarının ilkokul-ortaokul (Brown ve Redmod, 2007; Brown ve Reeves, 2009; Duran, Doruk ve Kaplan, 2017; Krummheuer, 2007; Mueller, 2009; Mueller ve Yankelewitz, 2014); bazılarının lise (Küçük Demir, 2014; Mercan, 2015); üniversite (Dinçer, 2011; Doruk, 2016; Rasmussen vd., 2006; Sanchez ve Uriza, 2008) ve mezun öğrenciler (Inglis, Mejia-Ramos ve Simpson, 2007) üzerine odaklandıkları tespit edilmiştir.

Ortaokul öğrencileriyle yapılan çalışmalar incelendiğinde; Brown ve Reeves'in (2009) argümantasyon yöntemi ile ders işlenmesinin öğrencilerin katılımını, problem çözümlerinde matematiksel işlemleri kullanma düzeyini ve yeni yaklaşımlar geliştirme becerilerini artırdığını belirledikleri görülmüştür. Benzer şekilde, Duran, Doruk ve Kaplan (2017) da argümantasyon ile ders işleme üzerine yoğunlaşmış ve bu yöntemle gerçekleştirilen olasılık öğretiminin 8.sınıf öğrencilerinin matematik başarılarını artırdığı sonucuna ulaşmıştı. Brown ve Redmod (2007) ise derslerde işbirlikli argümantasyon etkinlikleri kullanmış ve bu etkinliklerin 6. ve 7. sınıf öğrencilerinin matematik öğrenme isteklerini arttırdığını belirlemiştir. Mueller (2009) grup halinde bulunan öğrencilerin çalışmalarına odaklanmış ve bu çalışmaların grup içerisindeki tartışmalarda fikir birliği oluşmasının yanı sıra argüman kalitesinin artmasına katkısı olduğunu belirtmiştir. Krummheuer (2007) de çalışmasında öğrencilerin matematik öğrenmelerinin, grup tartşsmasındaki katılımlarına bağlı olduğunu ifade etmiş ve farkı katılım düzeylerinin oluşturulan argümanları etkilediğini belirlemiştir. Buna ilaveten, gerekçelendirme yapan öğrencilerin sadece veri veya iddia oluşturanlardan daha çok matematik bilgisine sahip olduğu görülmüştür. 
Ulaşılan çalışmalar incelendiğinde, alan yazında ortaokul öğrencilerinin problem çözme esnasında ortaya koydukları argümantasyon süreçlerinin belirlenmesi bağlamında eksiklik olduğu düşünülmektedir. Bu çalışmalar incelendiğince, araştırmaların genellikle derslerde argümantasyon yöntemi kullanılması ile farklı değişkenler arasındaki ilişkilerin araştırıldığı nicel çalışmalar oldukları görülmüştür. Inglis, Mejia-Ramos ve Simpson'un (2007) da belirttiği gibi öğrencilerin matematiksel problem çözümlerinin küçük yaşlardan itibaren argümantasyon süreci bağlamında gerçekleşmesi gerekmektedir. Çünkü bu süreçte öğrenciler neden-sonuçları birlikte yorumlayarak çözüme gidebilmekte, birbirleriyle etkileşim halinde olduklarından dolayı ise söylenilenler üzerinde derinlemesine düşünme ve sorgulama imkânı bulmaktadırlar (Şekerci, 2013). Buna ek olarak, argümantasyon süreci öğrencilerin bir konu hakkındaki düşüncelerini ortaya çıkarmanın yanı sıra kendi eksikliklerini görmelerine yardımcı olmakta (Akpınar ve Ergin, 2005) ve tartışma becerilerinin gelişmesine de katkı sağlamaktadır (Toulmin, 1958). Diğer bir deyişle, argümantasyon sürecinin öğrenciler açısından birçok yararı olduğu, problem çözüm sürecinde tartı̧ma ortamı oluşmasına ve bu sayede öğrencilerin sorgulamalar yaparak çözüme ulaşmasına olanak tanıdığı söylenebilir. Bu doğrultuda, öğrencilerin problem çözme esnasında ortaya koydukları argümantasyon süreçlerini, ilgili bileşenler bağlamında ayrıntılı olarak incelemeye olanak tanıyan nitel çalışmaların yapılmasının gerekli olduğu düşünülmektedir. Problem çözme bağlamında argümantasyon sürecinin incelenmesi, öğrencilerin deneyim kazanmalarına, eksikliklerini tamamlamaya yönelik çalışmalar yapılmasına, gelecekte kendi sorunlarını çözebilen bireyler olarak yetiştirilmeleri adına hem onlara hem de öğretmenlere yarar sağlayabilir. Tüm bunlardan hareketle yapılan bu çalışmada, 8. sınıf öğrencilerinin matematiksel problemler bağlamındaki argümantasyon süreçleri incelenmiştir. Bu amaç doğrultusunda;

- Öğrenciler problem çözme süreçlerinde hangi argümantasyon bileşenlerini kullanmaktadır?

- Öğrencilerin uygulama sürecine yönelik görüşleri nelerdir?

sorularına cevap aranmıştır.

\section{Yöntem}

\section{Araştırma Deseni}

Araştırmada nitel araştırma modellerinden biri olan özel durum çalışması kullanılmıştır. Özel durum çalışması "olayı gerçekleştiği doğal ortamında derinlemesine gözlemlemeye, sistematik bir biçimde veri toplamaya, analiz etmeye, sonuçları ortaya koymaya olanak sağlamasının yanı sıra özellikle bireysel olarak yürütülen çalışmalar için uygun olması" (Çepni, 2009, s.66) nedeniyle bu araştrrma için uygun bir modeldir.

\section{Çalışma Grubu}

Çalışma grubu, amaçlı örnekleme yöntemlerinden benzeşik örnekleme yöntemi ile seçilmiştir. Benzeşik örneklemede amaç küçük, benzeşik bir örneklem oluşturma yoluyla belirgin özelliklere sahip bir alt grubu tanımlamaktır (Yıldırım ve Şimşek, 2013).

Öğrencilerin seçimlerinde TEOG puanı da dâhil 2016-2017 eğitim-öğretim yılı birinci dönemindeki üç matematik sınavının ortalamaları, öğretmen görüşleri ve gönüllük ilkesi benimsenmiștir. Ortalamaları 90-100 arasında olup öğretmenleri tarafindan, okuduğunu anlayabilme, yorum yapabilme, duygu ve düşüncelerini rahat ifade edebilme, alternatif çözüm sunabilme becerileri yüksek olan öğrencilerden gönüllük esası da göz önüne alınarak üç öğrenci belirlenmiștir. Uygulanan metodolojik yaklaşımın bileşenleri düşünüldüğünde hipotez kurup bunları nedenlendirebilen öğrencilere gereksinim duyulması nedeniyle akademik başarıları yüksek öğrenciler tercih edilmiştir. Seçilen öğrencilerin ikisi kız, biri erkektir. Öğrencilerin yaşları 13-14 arasında olup sosyoekonomik düzeyleri birbirine yakındır. Çalışmada araştırma etiği açısından öğrencilerin gerçek isimleri yerine Yonca, Canan ve Mehmet şeklinde takma isimler kullanılmıştır. Yonca'nın matematik ortalaması 96, Canan'ın 91, Mehmet'in ise 93'tür.

\section{Veri Toplama Araçları ve Verilerin Toplanma Süreci}

Veri toplama aracı olarak iki problem çözme etkinliği, yarı yapılandırılmış görüşme formu, video ve ses kayıt cihazları kullanılmıştr. Belirlenen problemler, Ek 1 ve Ek 2 te verilen "Saksı Problemi" ve "Taksi Problemi" dir. Yarı yapılandırılmış görüşme formu ise 6 maddeden oluşmakla birlikte Ek 3'te sunulmuştur.

Problem çözme etkinlikleri oluşturulurken, öncelikle ilgili literatür (yüksek lisans, doktora tezleri, makaleler, ulusal ve uluslararası sınav soruları, matematik ders-çalışma kitapları) taranmıştı. Bu tarama sonucunda birden fazla yolla çözülebilen rutin olmayan problemlerden meydana gelen bir madde havuzu oluşturulmuştur. Madde havuzundaki problemlerin, öğrenci seviyesine uygunluğuna, rahatlıkla anlaşılır olup olmadığına, birden fazla yolla çözülebilirliğine yönelik üç uzman görüşü (üçü de üniversitede matematik eğitiminde görev yapan akademisyen) alınmış ve gerekli düzeltmeler

| Kastamonu Eğitim Dergisi, 27(4), 2019| 
yapılmıştır. İki Türkçe öğretmenine (ikisi de MEB'de çalışıyor) danışılarak problemlerde anlaşılır olmayan ifadeler düzeltilmiş, problemlerden anlam bozukluğu oluşturan bazı ifadeler silinmiş, problemler anlatım, noktalama ve imla kuralları açısından tekrar düzenlenerek, son şekli verilmiştir. Alınan uzman görüşleri sonucunda araştırmada kullanılmak üzere iki problem çözme etkinliği belirlenmiştir.

Yarı yapılandırılmış görüşme formu öğrencilerin uygulama sürecine yönelik görüşlerini belirlemek amacıyla araştırmacı tarafindan geliştirilmiştir. Geliştirilen görüşme formu hazırlanırken; soruların kolaylıkla anlaşıması ve çok boyutlu olmaması, yanıtlayan kişiyi yönlendirmemesi gibi ilkelere dikkat edilmiştir (Bogdan ve Biklen, 1992). Formun geçerliğini sağlamak adına üç uzman görüşü (üçü de üniversitede matematik eğitiminde görev yapan akademisyen) alınmıştır. Uzman görüşleri doğrultusunda forma son şekli verilerek 6 maddeden oluşan yarı yapılandırılmış görüşme formu araştırma için hazır hale getirilmiştir.

Öğrencilerin üç kişilik grup olarak yürüttüğü problem çözüm süreci, onların rahat edebilecekleri bir yer olması açısından araştırma kapsamında seçilen okulun kütüphanesinde gerçekleştirilmiştir. Öğrenciler bir masa etrafinda toplanmıştr. Öğrenciler problemi rahat okuyabilsinler diye problem durumları üç öğrencinin de önüne konmuştur. Araştrrmacı, öğrencilerin yaptı̆ı işlemleri takip edebilmek için yanlarına oturmuştur. Araştırmacı grup içinde sürdürülebilir bir tartışma ortamının olması ve öğrencilerin tartışma ortamına katılmalarını sağlamak amacıyla öğrencilere gerekli yerlerde "Neden böyle düşünüyorsun?", "Arkadaşlarının fikrine katlıyor musun, neden?" gibi teşvik edici sorular yöneltmiştir. Öğrenciler çalışma sürecinin ilk haftasında "Saksı Problemi”ni, ikinci haftasında "Taksi Problemi”ni çözmüşlerdir. Bu iki süreç video kayıt altına alınmıştır. İlk problemin çözüm süreci 18.07, ikincininki 22.08 dakika sürmüştür. Uygulama sonrası araştırmacı, öğrencilerle bire bir görüşme yapmıştır. Öğrenciler ile araştırmacı arasında meydana gelen her bir mülakat sürecinde veri kaybı yaşamamak adına ses kayıt cihazı kullanılmıştır.

\section{Verilerin Analizi}

Problem çözme etkinlikleri sırasında elde edilen video kayıtları ile yarı yapılandırılmış görüşme uygulaması sırasında elde edilen ses kayıtları öncelikle bilgisayara aktarılmış, daha sonra ise kelimesi kelimesine yazılı metine dönüştürülmüştür. Öğrenciler arasında meydana gelen tartş̧malar problemin anlaşılması, plan oluşturma, planı uygulama ve değerlendirme aşamaları bağlamında Toulmin modelinden yararlanılarak öğelerine ayrılmıştır. Çalışmada Toulmin modelinin -giriş kısmında belirtilen- iddia, veri, gerekçe, çürütücü, destekleyici ve niteleyici şeklindeki alt bileşenine ek olarak soru bileşeni kullanılmıştr. Bu bileşenlere ait açıklamalar ve yol gösterici örnekler oluşturulurken Toulmin'in (1958) görüşlerine bağlı kalınmıştır. Öğrencilerin grup halinde gerçekleştirdikleri problem çözüm süreçlerinden elde edilen veriler Tablo 1'deki açıklamalara uygun bir şekilde analiz edilmiştir.

Tablo 1. Problem Çözüm Sürecindeki Verileri Analiz Etmede Kullanılan Tematik Çerçeve ve Yol Gösterici Örnekler

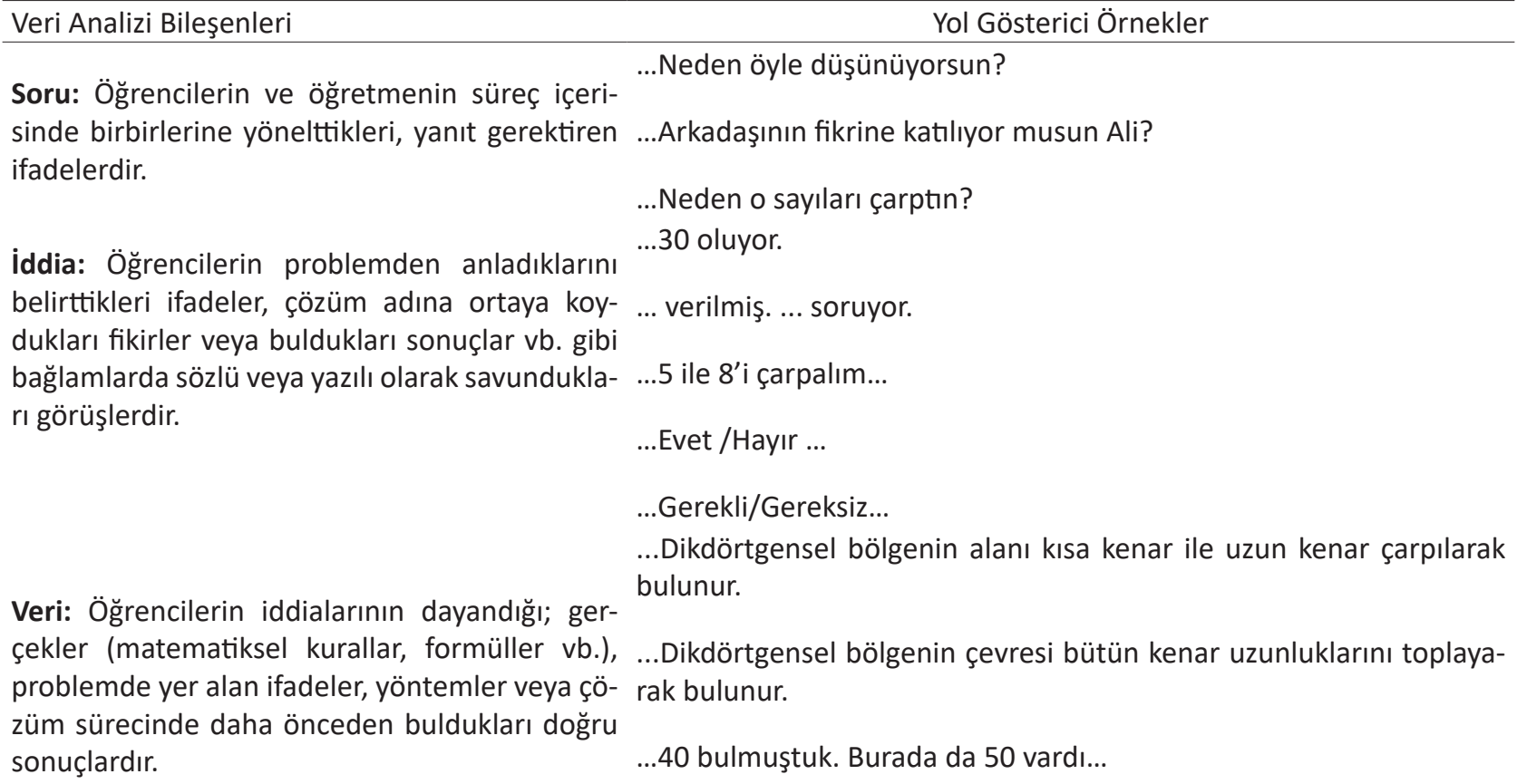

... (70'i nasıl buldun?) 10 ile 7'yi çarptım... 
...Alanı bulmak için kısa kenarla uzun kenarı çarptığımızdan dolayı 5

Gerekçe: Veriler ile iddialar arasındaki ilişkiyi or- ile 6'yı çarptım.

taya koyan ifadelerdir.

...Çevresini bulmak için iki kısa, iki uzun kenarı topladığımız için iki tane 5, iki de 6'yı topladım.

Çürütücü: Gerekçelerin geçerli olmadığı durum- ...Çevresini sorsaydı kenarlarını toplayacaktık. ları açıklayan ifadelerdir. Karşıt örnekler de çürütücü içinde ele alınmaktadır.

...Alanını sorsaydı kenarlarını çarpacaktık.

...Çevresini cm değil de mm olarak sorsaydı yanına sıfır ekleyecektik.

Destekleyici: Gerekçeleri destekleyen ve daha ...5 br ve 6 br'den oluşan dikdörtgensel bölgeyi 5 satır 6 sütuna ayırırgüçlü kılan açıklamalardır. sam içinde 30 tane birim kare oluyor. Bu nedenle alanı 30 br $^{2}$ çıkıyor. Niteleyici: İddianın kesinlik derecesini belirten ...Dikdörtgensel bölgenin alanını bulmak için kısa ile uzun kenarı ifadelerdir. çarptığımızda her zaman sonuca ulaşırız.

Cevap kesinlikle ...

Öğrencilerle yapılan görüşmelerden elde edilen ses kayıtları bilgisayara aktarılmış, daha sonra ise kelimesi kelimesine (gülüşme, cevap vermeme, mimikler gibi durumlar köşeli parantez içerisinde gösterilmiştir) yazılı metine dönüştürülmüştür. Elde edilen bu veriler ise betimsel analiz yaklaşımı kullanılarak çözümlenmiştir. Yıldırım ve Şimşek'e (2011, s.256) göre araştırmalarda kullanılan betimsel analiz dört aşamadan oluşmaktadır. Bu dört aşamada yapılanlar şu şekilde belirtilmiştir:

Betimsel analiz için bir çerçeve oluşturulması: Öğrencilerin sürece yönelik görüşlerini incelemek için Akı ve Gürel'in (2016) çalışmalarında kullanmış oldukları çerçeveden yararlanılmıştr. Bu çerçeve bilişsel, duyuşsal, sosyal paylaşım, dilsel deneyim olmak üzere dört temadan oluşmaktadır. Bu temaların kodları Akı ve Gürel'in (2016) görüşlerine bağlı kalınarak uzman görüşleri doğrultusunda oluşturulmuştur. Oluşturulan tematik çerçeve Tablo 2'de gösterilmiştir.

Tablo 2. Görüşme Sürecindeki Verileri Analiz Etmede Kullanılan Tematik Çerçeve ve Yol Gösterici Örnekler

\begin{tabular}{ll}
\hline \multicolumn{1}{c}{ Temalar } & Yol gösterici Örnekler \\
\hline \multirow{2}{*}{ Bilişsel Deneyim } & ilerde benzer bir problemle karşılaşsam yapabilirim. \\
& Denklem ile problemi çözmek kolaydı. \\
& Denklem oluşturmak zordu. \\
& Süreç ilgi çekici ve eğlenceliydi. \\
Duygusal Deneyim & Sıkıldım/Sıkılmadım. \\
& Kötü hissettim. \\
Dilsel Deneyim & Dilsel olarak fikrimi anlatmak daha kolay oluyor. \\
Sosyal Paylaşım Deneyimi & Dayanışmayla problemi hızlı çözdük. \\
& Grupça problemi çözmek tek başına çözmeye göre daha kolaydı. \\
\hline
\end{tabular}

Verilerin işlenmesi: Bu aşamada, bir önceki aşamada oluşturulan tematik çerçeveye bağlı olarak veriler okunarak düzenlenmiştir. Verilerin tanımlama amacıyla seçilmesi söz konusu olduğu için tema ile ilişkili veriler bir araya getirilirken, ilgili olmayan veriler ise dışarıda bırakılmıştır, bulgular kısmında yazılacak doğrudan alıntılar da seçilmiştir.

Bulguların tanımlanması: Bu aşamada düzenlenen veriler gerekli görüldüğü yerlerde doğrudan alıntlarla betimsel olarak sunulmuştur.

Bulguların yorumlanması: Bu aşamada bulguların açıklanması, birbirleriyle ilişkilendirilmesi yapılmıştır. Gerekli görüldüğü yerlerde katılımcıların durumları karşılaştırılmıştır.

Betimsel analizin kullanıldığı bu çalışmada, geçerliliği sağlamak üzere veriler açık uçlu problemler ve yarı yapılandırılmış görüşmeler yardımıyla toplanarak veri çeşitlemesine gidilmiştir. Veriler toplanıp transkript edildikten sonrada hazırlanan dokümanlar katlımcılara dağıtılıp yazılanların doğru olduğuna yönelik onay alınmıştr. Ayrıca çalışmanın süreci ayrıntılı bir şekilde açıklanmaya çalışılarak, verilerden elde edilen bulgular kathlımcıların verdikleri cevaplardan doğrudan alıntılar yapılarak sunulmuştur. Öğrencilerin cevaplamalarındaki tematik kodlamalar yapııırken ise argümantasyon konusunda çalışma yapan iki öğretim üyesinin görüşlerine başvurulmuştur. Uzman değerlendirmelerindeki görüş birliği Miles ve Huberman'ın (1994) belirttiği şu formülle hesaplanmıştır: Uzlaşma Yüzdesi=[Görüş Birliği/(Görüş Birliği+ Görüş 
Ayrılığı)] x 100. Bu hesaplama sonucu uzlaşma yüzdesi 95 olarak bulunmuş ve belirlenen kategorilerin tutarlı olduğu sonucuna ulaşılmıştır. Uzlaşma sağlanamayan sorular tam bir sınıflama uzlaşması sağlanana kadar tekrar incelenmiş ve üzerinde tartşılmıştı. Diğer yandan çalışmanın güvenirliği için, veriler betimsel bir yaklaşımla önceden oluşturulmuş tematik çerçevelere göre analiz edilerek diğer araştırmacıların görüşlerine açık olmak üzere kayıt altına alınmıştır.

\section{BULGULAR}

Bu bölümde araştırmanın alt problemlerine yanıt bulabilmek için öğrencilerin süreç içerisinde ortaya koydukları argümantasyon bileşenlerine ve sürece yönelik görüşlerine yer verilmiştir.

\section{Öğrencilerin Süreç İçerisinde Ortaya Koydukları Argümantasyon Bileşenleri}

Bu kısımda, çalışma grubunun problem çözüm süreçlerinden elde edilen veriler Tablo 1'de yer alan bileşenlere göre sunulmuştur. İlk olarak "Saksı Problemi", daha sonra "Taksi Problemi" bağlamında elde edilen verilere yer verilmiştir.

\section{Tablo 3. "Saksı Problemi"nin Anlaşılma Süreci}

\begin{tabular}{ccc}
\hline 1 & Yonca: Şu saksı getirmezse kısmı önemsiz. & İdia \\
2 & Araştırmacı: Şimdi saksı getirmezse kısmı gereksiz öyle mi? & Soru \\
3 & Canan: Evet önemsiz. & İddia \\
4 & Yonca: Bence müşteri gelip alırsa kısmı da gereksiz. & İddia \\
\hline
\end{tabular}

Tablo 3 incelendiğinde, Yonca'nın problemde gereksiz bir kısmın olduğunu iddia ettiği (1) görülmüştür. Bunun üzerine araştırmacı, Yonca'nın iddiasını soru şeklinde öğrencilere yöneltmiştir (2). Canan da problemde "saksı getirmezse" kısmının önemsiz olduğunu belirtmiştir (3). Buna ek olarak Yonca, "müşteri gelip alırsa” kısmının da gereksiz olduğunu iddia etmiştir (4).

\section{Tablo 4. "Saksı Problemi"nin Plan Oluşturma Süreci}

1

3

4

5

6
Yonca: 1,4 ile 5'i çarpmalıyız. Adrese teslim edilse 1,4 liradan hesaplanacak deniyor. Bu nedenle beş taneyi bulmak için bunu 5 ile çarpacağız.

Canan: "40 lira ödeyen biri kaç çiçek almış olur" ifadesi kaç saksı almış olur demek.

Mehmet: Müşteri saksı getirmezse kısmı da bizim için önemli.

Araştırmacı: Demin niye önemsiz dediniz?

Mehmet: Önemli. Adam kendi saksı getirmeli ki 40 lira olsun. Yonca: Bence de önemli, şu an bana da mantiklı geldi.
İddia, Veri, Gerekçe

$$
\begin{gathered}
\text { İddia } \\
\text { İddia } \\
\text { Soru } \\
\text { İddia, İddia } \\
\text { İddia }
\end{gathered}
$$

Tablo 4 incelendiğinde, Yonca'nın plan oluşturma bağlamında bir iddia öne sürdüğü, bunu dayandırdığ 1 ifadeyi belirterek ortaya bir veri koyduğu ve bu ikisi arasında bir gerekçelendirme yaptığı görülmüştür (1). Canan problemde istenen ifadenin ne anlama geldiğini açıklamaya yönelik bir iddiada bulunmuştur (2). Mehmet ise problemin anlaşılma sürecinde ortaya konulan iddianın aksine, "müşteri saksı getirmezse" ifadesinin önemli olduğuna yönelik bir iddia öne sürmüştür (3). Bunun üzerine araştırmacı öğrencilere bir soru yönlendirmiştir (4). Mehmet bu soruya iki iddia ile karşıllk vermiştir (5). Yonca Mehmet'in açıklamasının mantıklı olduğunu belirterek bir iddia ortaya koymuştur (6).

Tablo 5. "Saksı Problemi”nin Planı Uygulama Süreci

1
Yonca: 1,4 lirayı 5 ile çarpalım. 40 liradan 7'yi çıkarınca geriye kalan 33'ü 1,65'e bölelim. Canan: Virgül kaydırabiliriz.

Yonca: Canan'ın dediği gibi 33'ün yanına sıfir atıp diğerinde virgül kaydırırsak 3300:165'ten cevap 20 oluyor. iki virgül kaydırırsak 0,20 oluyor [gülüyor].

Canan: [gülüyor] Bence cevap 2 oluyor.

Yonca: Çarpalım deneyelim, 1,65.20 işlemini yaptı̆ımızda cevap 33 ediyor.

Mehmet: Bence sağlamasını yapalım, 33 lirayı kuruşa çevirelim 3300 kuruş ediyor. Sonra bölelim.

Yonca: Bence cevap 27.

Araştırmacı: 27'yi nasıl buldun?

Canan: Ben de onu düşünüyorum, 25 oluyor.

Yonca: Neden?

Canan: Burada 5 tane vardi, biz de 20 tane bulduk. Toplam 25 ediyor.

Yonca: Doğru 25 oluyor.

İddia, İddia
İddia
İddia, İddia
İddia
İddia
İddia, İddia
İddia
Soru
İddia
Soru
Veri, İddia
İddia


Tablo 5 incelendiğinde, Yonca'nın planı uygulama bağlamında iki iddia ortaya koyduğu görülmüştür (1). Canan ise Yonca'nın söylediklerinin devamını getirerek 33'ü 1,65’e bölme bağlamında bir iddia ortaya koymuştur (2). Yonca, Canan'ın söylediği metodu uygulayarak 20 bulmuş ve virgülü iki sola kaydırmaları gerektiği şeklinde bir fikir dile getirmiştir (3). Sonucu 0,20 bulduktan sonra Canan, sonucun 2 olabileceğine dair bir iddia öne sürmüştür (4). Yonca deneme yapmış ve 1,65.20'nin sonucunun 33 olduğuna yönelik bir iddiada bulunmuştur (5). Bunun üzerine Mehmet 33 lirayı kuruşa çevirerek sonucu bulmaya dair iki iddia öne sürmüştür (6). Devamında, Yonca problemin cevabının 27 olduğunu iddia etmiş (7), araştırmacı 27'yi nasıl bulduğunu sormuştur (8). Canan ise sonucun 25 olması gerektiğine yönelik bir fikir dile getirmiştir (9). Yonca Canan'a neden bu şekilde düşündüğünü sormuş (10) ve Canan problemde verilen bir ifadeyi ve buldukları bir sonucu kullanarak cevabın 25 olması gerektiğini belirtmiştir (11). Bunun üzerine Yonca cevabın 25 olduğunu belirterek Canan’a katıldığını söylemiştir (12).

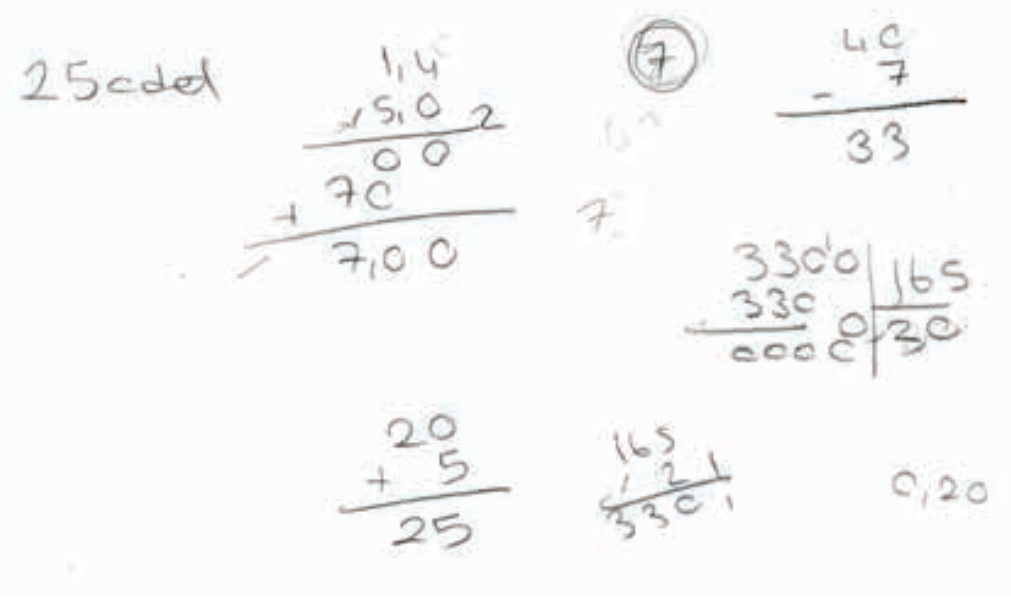

Şekil 1. Öğrencilerin "Saksı Problemi” İçin Yaptı̆ı̆ illk Çözüm Örneği

Tablo 6. "Saksı Problemi"nin Değerlendirme Süreci

\begin{tabular}{|c|c|c|}
\hline 1 & Araştırmacı: Problemi denklem kurarak çözebilir misiniz? & Soru \\
\hline 2 & Yonca: Çözülebilir. & İddia \\
\hline 3 & Canan: 7+x eşittir diye yapacağız. & İddia \\
\hline 4 & Yonca: Fiyatlardan mı gitsek yoksa çiçek sayısından mı? & Soru \\
\hline 5 & Canan: Fiyatlardan kurmayalım bence. Karışık olur. & İddia, İddia \\
\hline 6 & $\begin{array}{l}\text { Yonca: Bence fiyat ve kaç tane çiçek aldığını içeren karışık bir denklem olacak. Şöyle olsa } \\
\qquad(40-1,4.5) / 1,65+5 .\end{array}$ & İddia, İddia \\
\hline 7 & Araştırmacı: Bu ifadede neden hiç bilinmeyen yok? & Soru \\
\hline 8 & Yonca: Eşittir x diyelim, denklem olur. & İddia \\
\hline 9 & Mehmet: Buldum 5.1,4+1,65x=40 lira şeklinde olacak. & İddia \\
\hline 10 & Araştirmacı: Oldu mu sence? & Soru \\
\hline 11 & Yonca: Bakalım. 5 çarpı 1,4'ten yedi lira eder. Toplarsak 8,65x=40 & İddia, İddia \\
\hline 12 & Canan: 40’ 8,65'e bölelim. 4000 şeklinde yapalım onu. & İddia, İddia \\
\hline 13 & Araşttrmacı: 7 ile 1,65 toplanabiliyor mu orada? & Soru \\
\hline 14 & Yonca: Evet toplanabilir. Bölersek 540 çıkt. & İddia, İddia \\
\hline 15 & Araşttrmacı: Mehmet sence de 8,65 oluyor mu orası? & Soru \\
\hline 16 & Mehmet: Hayır olmuyor. & İddia \\
\hline 17 & Araştirmacı: Neden? & Soru \\
\hline 18 & Mehmet: Denklem çözerken çarpma yapılır, bu sayı karşı tarafa atılır. & Veri \\
\hline 19 & Araştırmacı: Yazın bakalım $2+3 x=5 x$, bu ifade doğru mu? & Soru \\
\hline 20 & Canan: Evet. & İddia \\
\hline 21 & Yonca: Yanlış bu. x'li ifade ile normal bir sayıyı toplayamayız ki. $2 x+3 x$ olsaydı $5 x$ olurdu. & İddia, İddia, Çürütücü \\
\hline 22 & $\begin{array}{l}\text { Mehmet: } 7 \text { ile 1,65x toplanamaz, çarpılabilir. Toplanması için bunların benzer terim ol- } \\
\text { ması gerek. Bunlar benzer terim olmadığı için toplanamaz. 7’yi karşıya atınca 1,65x=33 } \\
\text { oluyor. } 20 \text { çıkt, } 5 \text { de elimizde vardı. Toplam } 25 \text { eder. Sonuç kesinlikle } 25 .\end{array}$ & $\begin{array}{l}\text { İddia, Veri, Gerekçe, İddia, } \\
\text { Veri, İddia, Niteleyici-İddia }\end{array}$ \\
\hline
\end{tabular}


Tablo 6 incelendiğinde, araştırmacının öğrencilere problemi denklem yardımıyla çözüp çözemeyeceği bağlamında bir soru sorduğu görülmüştür (1). Yonca problemin bu şekilde çözülebileceğini iddia etmiştir (2). Canan ise "7+x=" şeklinde yapılacağını getirmiştir (3). Bunun üzerine Yonca grup arkadaşlarına bir soru sormuştur (4). Canan fiyatlardan gitmemeleri gerektiğine dair düşüncesini ifade etmiştir (5). Ardından Yonca denklemin nasıl olacağına dair görüş ileri sürmüş ve sayısal bir ifade ile fikrini belirtmiştir (6). Araştırmacı Yonca'ya yazdığı ifadede neden bilinmeyen olmadığını sormuş (7) bunun üzerine Yonca "eşittir x" diyerek iddiasını tamamlamıştı (8). Bu sırada Mehmet problem için kullanmaları gereken denklemi oluşturabildiğine yönelik bir iddia öne sürmüştür (9). Araştırmacı Mehmet'in kurduğu denklemin doğru olup olmadığına dair soru sormuş (10) ve Yonca denklemi çözmeye yönelik iddiada bulunmuş ve x'in katsayısı ile 7 sabitini toplayıp 8,65.x= 40 şeklinde yazmıştı (11). Canan Yonca'nın yazdığı eşitlikten bilinmeyeni bulmaya yönelik iki iddiada bulunmuştur (12). Araştırmacı 7 ile x'in katsayısının toplanabilirliğine yönelik bir soru sormuş (13) ve Yonca toplama işleminin yapılabileceğini, hatta sonucun 540 olduğunu iddia etmiştir (14). Mehmet'in bu süre zarfinda sessiz kalması sebebiyle araştırmacı Mehmet'e ifade edilen toplanabilirliğe yönelik soru sormuştur (15). Mehmet 7 ile 1,65 katsayısının toplanamayacağı yönünde bir fikir belirtmiştir (16). Araştırmacı bu durumun nedeninin sorduğunda (17), Mehmet iddiasına dayanak olan bir veri ortaya koymuştur (18). Bunun üzerine araştırmacı öğrencilere bir eşitlik vererek bu ifadenin doğruluğuna yönelik soru sormuştur (19). Canan bu eşitliğin doğru olduğunu belirtmiş (20), Yonca ise iki iddia ortaya koyarak ardından çürütücü kullanmıştır (21). Mehmet 7 ile 1,65' in toplanamayacağı iddiasını ve bu iddiasının dayanağını ortaya koymuş, bu ikisi arasında gerekçelendirme yapmışttr. Buna ek olarak Mehmet bilinmeyenin 20 olacağı yönünde bir iddia ortaya koymuştur (22). Ardından problemin cevabının 25 olması gerektiğini ve bu iddianın dayanağını belirterek bir niteleyici kullanmıştır (22).

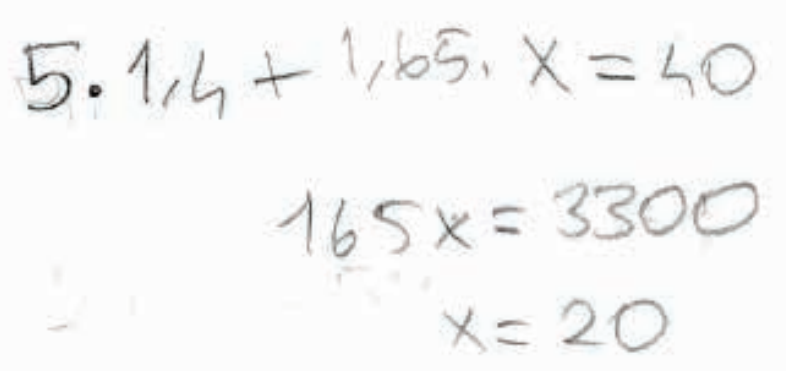

Şekil 2. Öğrencilerin "Saksı Problemi” İçin Yaptıkları İkinci Çözüm Örneği

Tablo 7. “Taksi Problemi”nin Anlaşılma Süreci

\begin{tabular}{ccc}
\hline 1 & Mehmet: Evden kaçta çıkacak? & Soru \\
2 & Araştırmacı: Önemli mi bu? & Soru \\
3 & Mehmet: Bence önemli. 15 dakika bekletecekmiş. Bunun için kaçta çıkacağı & İddia, Veri, Gerekçe \\
4 & Yonca: Bence önemli değil. Bizim için beklediği süre önemli. & İddia, Iddia \\
\hline
\end{tabular}

Tablo 7 incelendiğinde, Mehmet'in problemi anlamlandırmaya yönelik bir soru sorduğu (1) görülmüştür. Araştrrmacı bu durumun önemli olup olmadığına yönelik Mehmet'e bir soru (2) yönlendirmiştir. Mehmet bu durumun önemli olduğu şeklinde ortaya bir iddia atmıştı (3). Bunun yanı sıra iddiasını dayandırdığı ifadeyi ortaya koymuş ve iddiası ile verisi arasında bir ilişki kurmuştur (3). Yonca ise Mehmet'in iddiasına katılmayıp ortaya yeni iki iddia atmıştır (4).

Tablo 8. "Taksi Problemi”nin Plan Oluşturma Süreci

\begin{tabular}{|c|c|c|}
\hline 1 & Yonca: Toplam 8 km gitmiş, bence 8000 metreyi 50’ye bölelim. Sizce? & İddia, Soru \\
\hline 2 & Canan: Bence öyle yapılmayacak. & İddia \\
\hline 3 & $\begin{array}{c}\text { Yonca: Ama bak şöyle olacak, şimdi biz paraları hesaplayacağız. Bunu } \\
\text { 39'dan çıkıp onun km'sini hesaplayacağız. }\end{array}$ & İddia, İddia \\
\hline 4 & Araştırmacı: 8 km'yi mi kullanacaksınız yani? & Soru \\
\hline 5 & $\begin{array}{c}\text { Mehmet: Bence } 15 d k^{\prime} l ı k \text { bekleme parasını bulalım. 3,5 lira ile toplaya- } \\
\text { lım. Çıkan sayıyı } 39 \text { liradan çıkalım. }\end{array}$ & İddia, İddia, İddia \\
\hline 6 & Yonca: Bence de, 15 ile 0,30'u çarpalım. & İdia \\
\hline
\end{tabular}


Tablo 8 incelendiğinde, Yonca'nın plan oluşturma bağlamında iddia ürettiği, ardından grup arkadaşlarına bir soru yönelttiği görülmüştür (1). Canan ise konuşma sürecinde ilk defa aktif olmuş ve Yonca'ya katılmadığını belirtmiştir (2). Konuşmanın devamında Yonca plan kurmaya yönelik iki iddia daha ortaya koymuştur (3). Araştırmacının yönelttiği bir soru (4) üzerine, Mehmet çözüm adına iddialar öne sürmüştür (5). Bunun üzerine Yonca, Mehmet’e katıldığını belirtmiş ve yeni bir iddia dile getirmiştir (6).

\section{Tablo 9. “Taksi Problemi”nin Planı Uygulama Süreci}

\begin{tabular}{|c|c|c|}
\hline 1 & Canan: 45 lira ediyor. & İddia \\
\hline 2 & Mehmet: 4,5 lira oluyor. & İdia \\
\hline 3 & $\begin{array}{c}\text { Yonca: Evet 4,5 oluyor. Şimdi gittiği yolun ne kadar para ettiğini bulalım, ev ile şantiye arası } 5 \text { km, } \\
\text { bunu 50'ye bölelim, sonra } 25 \text { ile çarpalım. Yoksa } 8 \text { km'yi mi yapalım bu şekilde? }\end{array}$ & İddia, İddia, Soru \\
\hline 4 & $\begin{array}{c}\text { Canan: Bence doğru olan 8'i değil de 5'i yapmak. Adam hava alanına gitti demiyor. Bu nedenle } 5 \\
\text { km'den gitmeliyiz. }\end{array}$ & İddia, Veri, Gerekçe \\
\hline 5 & Yonca: Şantiye ile restoran arası 3 km'den az. Buranın tamamı 3 km deniyor. & İddia, Veri \\
\hline 6 & Mehmet: Bence her 50 metrede 25 kuruş ise 1 km'de ne kadar ettiğini bulmamız daha doğru olur. & İddia \\
\hline 7 & Canan: 39 lirayı 25 kuruşa bölelim bence. & İddia \\
\hline 8 & $\begin{array}{c}\text { Yonca: Mehmet'in dediği gibi } 1 \text { km’nin ne kadar ettiğini bulalım, şu an restoran ile hava alanı me- } \\
\text { safenin önemi yok. }\end{array}$ & İddia \\
\hline 9 & Mehmet: (zihninden hesapladı) 5 lira eder. & İddia \\
\hline 10 & Yonca: [şaşkın bir şekilde gülüyor] 1 km 1000 metre eder, 50'ye bölersek 20 olur. & İddia \\
\hline 11 & Mehmet: Öyle değil, şöyle olacak, 200 metrede 1 lira ediyor. 5 ile çarparsak 5 lira ediyor. & İddia, İddia \\
\hline 12 & $\begin{array}{l}\text { Yonca: Bence } 3 \text { km'yi bulalım, } 15 \text { lira eder. Toplayıp } 39 \text { çıkarınca giden yolu, şantiye restoran arası- } \\
\text { nı, buluruz. 3,5+4,5+5+15=28 lira eder. }\end{array}$ & İddia, İddia, İddia \\
\hline 13 & $\begin{array}{c}\text { Mehmet: Bence bekleme ile açılış fiyatlarını toplayalım, } 8 \text { lira eder. 39'dan bunu çıkarınca geriye } 31 \\
\text { lira üstünden gidelim. } 1 \text { km } 5 \text { liraydı. Buradan } 6 \text { km } 30 \text { lira eder. Geriye kalan } 1 \text { lira da } 200 \text { metre } \\
\text { yapıyor. Demek ki } 6 \text { km } 200 \text { metre. }\end{array}$ & $\begin{array}{l}\text { İddia, İddia, Veri, } \\
\text { İddia, İddia, İddia }\end{array}$ \\
\hline 14 & $\begin{array}{c}\text { Araştırmacı: Ama demin Yonca dedi ki } 3 \text { km'den az olacak, siz } 6200 \text { buldunuz, bu şekilde nasıl } \\
\text { oluyor? }\end{array}$ & Soru \\
\hline 15 & Yonca: Evet Mehmet tamamı 3 km. Bura 6200 olmaz. & Veri, İddia \\
\hline 16 & $\begin{array}{l}\text { Mehmet: (problemi yeniden okudu) Benim bulduğum şey, ev ile restoran arası. Ahmet Bey evden } \\
\text { çıkıyor denmiş. Ve ev ile şantiye arası } 5 \mathrm{~km} \text {. Bu nedenle geri kalan problemin cevabı olacak. }\end{array}$ & $\begin{array}{l}\text { İddia, Veri, Veri, } \\
\text { Gerekçe }\end{array}$ \\
\hline 17 & Yonca: Anladım, cevap 1200 metre olmalı. & İddia \\
\hline
\end{tabular}

Tablo 9 incelendiğinde, Canan'ın planı uygulama bağlamında bir iddia ortaya koyduğu görülmüştür (1). Mehmet bu sonucun 45 olamayacağına dair bir iddia öne sürmüştür (2). Ardından, Yonca Mehmet'in iddiasını onaylayarak çözüm adına kendi de bir iddia ortaya koymuş ve grup arkadaşlarına bir soru yöneltmiştir (3). Bunun üzerine Canan Yonca'nın sorusuna karşııı bir iddia ortaya koymuş ve bu iddiasının dayanağını belirterek gerekçelendirme yapmıştır (4). Devamında, Yonca sonucun ne olabileceğine dair bir iddia ortaya koymuş ve neye göre bu şekilde düşündüğünü ifade etmiştir (5). Mehmet (6) ve Canan (7) çözüm adına farklı iddialar öne sürmüştür. Yonca, Mehmet'in iddiasını onaylamış ve restoran ile hava alanındaki uzaklığın önemli olmadığına dair bir iddia ortaya koymuştur (8). Ardından Yonca söz konusu 1 kilometrelik yolun fiyatının kaç lira ettiğini bulmaya çalışmış, Mehmet zihninden hesaplamalar yaparak ortaya bir iddia koymuştur (9). Yonca, Mehmet'in sonucu zihinden bulmasına şaşırmış ve 1 kilometrenin kaç lira ettiğini kendisi de hesaplamaya çalışmıştır (10). Yonca 1 kilometreyi 1000 metreye dönüştürüp içinde kaç tane 50 olduğunu bulmaya yönelik bir iddia öne sürmüş fakat devamını getirememiştir (10). Bunun üzerine Mehmet belirtilen durumun nasıl hesaplanacağına dair birçok iddia öne sürmüştür (11). Yonca Mehmet'i onaylamış ve çözümü devam ettirmeye yönelik çeşitli iddialar ortaya koymuştur (12). Mehmet çözüm adına daha önce buldukları bir sonuna dayanarak farklı iddialar öne sürmüş ve sonucun 6200 metre olması gerektiğini belirtmiştir (13). Bunun üzerine araştırmacı öğrencilere bir soru yöneltmiştir (14). Bu soru üzerine Yonca bir iddia ve bu iddiasının dayanağını ifade etmiştir (15). Bu süre zarfinda, Mehmet problemi yeniden okumaya başlamış ve 6200 kilometrenin ev ile restoran arasındaki uzaklık olduğu yönünde bir iddia ortaya koymuştur (16). Daha sonra bu iddiasına dayanak olan verileri kullanarak gerekçelendirme yoluna gitmiştir (16). Yonca Mehmet'i anladığını belirterek sonucun 1200 olacağı şeklinde iddia öne sürmüştür (17). 


\section{Tablo 10. "Taksi Problemi"nin Değerlendirme Süreci"}

1 Yonca: illk açılıș parasını ekledik, sonra $15 \mathrm{dk}$ bekletti çarptık 4,5 lira çıktı. Km başına 5 lira çıkmışt. Buradan $5 \mathrm{~km} 25$ lira eder. Ev ve şantiye arasındaki yolun fiyat 25 lira yani. Şantiye hava alanı arasındaki yolun fiyati 9 lira.

2

3

4

5

6

7
Mehmet: 9 lira olmayacak. 6 lira olacak. Hava alanına gitmedi.

Yonca: Doğru. Şantiye restoran arası 6 lira ediyor. Şimdi toplayalım 3,5+4,5+25+6=39 lira ediyor.

Araştırmacı: Sonuçtan emin misiniz yani?

Mehmet: Kesinlikle doğru bulduk.

Yonca: Yüzde yüz eminim.

Canan: Bence de kesinlikle bu.
İddia, Veri, İddia, İddia, İddia

İddia, İddia, Veri

İddia, İddia, İddia

Soru

Niteleyici-İddia

Niteleyici-idddia

Niteleyici-Iddia

Tablo 10 incelendiğinde, Yonca'nın problemin değerlendirme sürecini başlattğı görülmüştür (1). Yonca bir iddia ile konuşmasına başlamış ve bir dayanağa bağlı olarak ortaya çeşitli iddialar koymuştur (1). Ardından Mehmet Yonca'nın son belirttiğinden farklı bir iddia öne sürerek açıklamasını devam ettirmiştir (2). Bunun üzerine Yonca'nın buldukları sonucu değerlendirmeye yönelik çeşitli iddialar ortaya koymuştur (3). Araştırmacının öğrencilere yönelttiği soruyu (4) öğrenciler niteleyici bileşeni kullanarak cevap vermiş $(5,6,7)$ ve buldukları sonuçtan emin olduklarını dile getirmişlerdir.

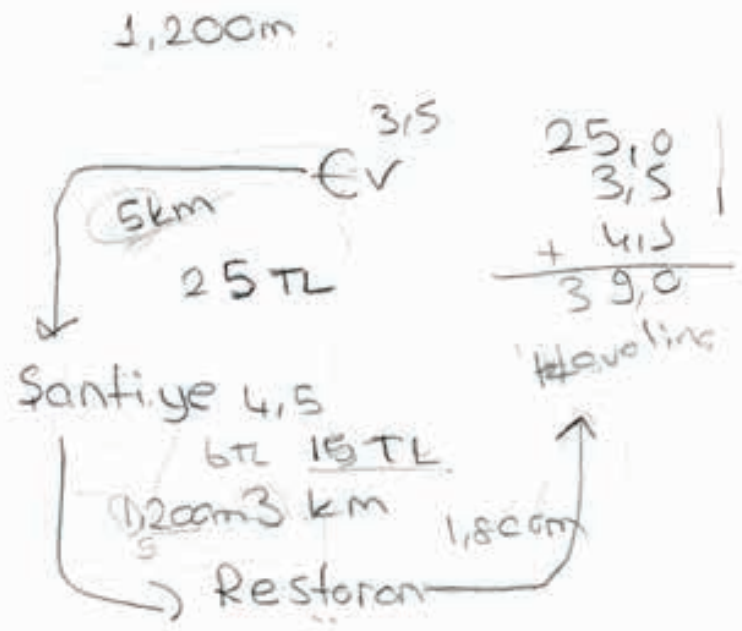

\section{Şekil 3. Öğrencilerin "Taksi Problemi” İçin Yapttğı Çözüm Örneği}

Öğrencilerin iki problem çözüm sürecinde veri, iddia, gerekçe, destekleyici, çürütücü ve niteleyici bileşenlerinin her birini ne sıkıkta kullandıklarına ilişkin bulgular Tablo 11'de gösterilmiştir (Sadece öğrencilerin yönelttiği soru sayıları belirtilmiştir).

Tablo 11. Öğrencilerin Problemlerde Kullandıkları Argümantasyon Bileşenleri ve Bu Bileşenlerin Kullanım Sayıları

\begin{tabular}{ccccccccc}
\hline & Soru & Veri & İdia & Gerekçe & Destekleyici & Çürütücü & Niteleyici & $\begin{array}{c}\text { Argüman } \\
\text { Sayısı }\end{array}$ \\
\hline Saksı Problemi & 3 & 5 & 44 & 2 & 0 & 1 & 1 & 56 \\
Taksi Problemi & 3 & 9 & 50 & 3 & 0 & 0 & 3 & 68 \\
\hline TOPLAM & 6 & 14 & 94 & 5 & 0 & 1 & 4 & 124 \\
\hline
\end{tabular}

Tablo 11 incelendiğinde öğrencilerin "Saksı Problemi"nin çözüm sürecinde 3 soru, 5 veri, 44 iddia, 2 gerekçe, 1 çürütücü ve 1 niteleyici; “Taksi Problemi”nin çözüm sürecinde ise 3 soru, 9 veri, 50 iddia, 3 gerekçe ve 3 niteleyici kullandıkları görülmüştür. İki problem süreci birlikte ele alındığında ise öğrencilerin toplamda 6 soru, 14 veri, 91 iddia, 5 gerekçe, 1 çürütücü ve 4 niteleyicinin kullandıkları tespit edilmiştir. Buna ek olarak, öğrencilerin "Saksı Problemi"nin çözüm sürecinde hiç destekleyici kullanmadıkları; "Taksi Problemi”nin çözüm sürecinde ise destekleyici ve çürütücü ortaya koymadıkları belirlenmiştir.

\section{Öğrencilerin Sürece Yönelik Görüşleri}

Tablo 2'deki tematik çerçeve doğrultusunda öğrenci görüşleri incelenerek aşağıda sunulmuştur.

Tematik çerçevenin ilk bileşeni olan bilişsel deneyim sürecinde öğrencilerin grupça tartşarak gerçekleştirdikleri problem çözümlerinde çeşitli deneyimler edindikleri söylenebilir. Örneğin; Yonca isimli öğrenci "Sorgulama yaparak 
problemi daha rahat anladım." söyleminde bulunurken Mehmet "Süreçte farklı fikirlerin ortaya çıkması çözümü kolaylaştırdı" şeklinde görüş bildirmiştir. Benzer şekilde Canan da bu durumu "Sorgulama yaparak problemi daha rahat çözdük." şeklinde ifade etmiş̧tir. Buna ek olarak Canan ve Mehmet ilerde benzer bir problemle karşılaştiklarında daha kolay çözebileceklerini söylemişlerdir. Öğrenciler grup olmanın problem çözüm sürecini hızlandırdığı yönünde görüş belirtmişlerdir. Bu doğrultuda Yonca "Dayanışmayla problem hızlı çözüldü. Bence problemi grup halinde çözmek tek başına çözmeye göre daha güzel."; Mehmet "Süreçte herkes bir şey söyledi, böylece sonuca daha rahat ulaştik." derken, Canan ise şunları dile getirmiştir: "Birlikte olunca herkes problemin bir yerinden tutuyor, bu nedenle daha hızlı çözülüyor.". Dolayısıyla sürecin öğrencileri sosyal paylaşım bağlamında etkilediği söylenebilir.

Yonca ile Mehmet düşüncelerini birbirlerine daha rahat anlatabileceklerinden dolayı aynı grupla yine benzer bir ortamda bulunmak istedikleri yönünde, oluşturulan öğrenme süreci ile ilgili görüşlerini bildirmişlerdir. Bu doğrultuda Yonca "Benim düzeyimde olan kişilerle benzer ortamda bulunmak isterim... Çünkü aynı düzeydeki öğrenciler birbirlerine fikirlerini daha rahat anlatabiliyorlar. Bunu süreçte daha iyi görmüş oldum." derken; Mehmet ise "Yine aynı kişilerle benzer ortamda bulunmak isterim. Çünkü bana göre aynı kişilere fikirlerimi anlatmak daha kolay olur. Çünkü birbirimize alıştk." yönünde açıklamada bulunmuştur. Dolayısıyla Yonca ve Mehmet'in dilsel boyut bağlamında deneyim edindikleri söylenebilir.

Öğrenciler süreç boyunca sıkılmadıkları, çok eğlendikleri yönünde görüş belirtmişlerdir. Örneğin; Yonca "Süreç bana göre eğlenceli geçti ve sıkılmadım.", Mehmet "Benim için farklı bir uygulama oldu. Güzel bir ortamdı. Eğlendim." derken, Canan ise "Süreç eğlenceli ve güzeldi, bu nedenle benzer bir ortamda tekrar bulunmak isterim." şeklinde açıklamada bulunmuştur. Buna ek olarak Canan "...süreçte arkadaşlarım önerdiğim iddiamı çürüttükleri zaman kendimi kötü hissediyordum. Ama daha sonra aklıma yatınca moralim düzeldi." yönünde açıklamada bulunmuştur. Bu görüşler göz önüne alındığında Canan ve Yonca'nın duygusal boyut bileşeni kapsamında deneyim kazandıkları söylenebilir.

Öğrencilerle yapılan mülakat süreci incelendiğinde; sorgulayarak problem çözme sürecinin, kendilerine bilişsel, duyuşsal, sosyal paylaşım ve dilsel bileşenler bağlamında katkı sağladığı yönünde açıklamalarda bulundukları görülmüştür. Diğer bir deyişle, öğrenciler grup halinde çalışmanın ve sorgulama yapmanın problem çözme sürecini kolaylaştrdığını, sürecin eğlenceli olduğunu, yine aynı kişilerle benzer ortamda bulunmak istediğini ifade etmişlerdir.

\section{Tartışma ve Sonuç}

8. sınıf öğrencilerinin matematiksel problemler bağlamındaki argümantasyon süreçlerinin incelendiği bu çalışmada öğrencilerin argümantasyon bileşenlerinden en çok iddia (94), en az ise destekleyici (0) bileşenini kullandıkları sonucuna ulaşılmıştı. İddia ve destekleyici arasında kalan bileşenlerin kullanılma sıklığı sırasıyla veri (14), soru (6), gerekçe (5), çürütücü (1) şeklindedir. Benzer şekilde Duran, Doruk ve Kaplan (2017) öğrencilerin uygulama süresince en çok iddia bileşeni kullanmalarına rağmen tartşmalarında az sayıda destekleyici ve çürütücüye yer verdiklerini belirlemişlerdir. Çinici vd. (2014) öğrencilerin çok fazla sayıda iddia kullandıklarını, buna rağmen çürütücü üretmede yetersiz kaldıkları sonucuna ulaşmıştr. Aymen Peker, Apaydın ve Taş (2012) öğrencilerin iddiayı diğer bileşenlerden daha sık kullandıklarını, çürütücü sunmada ise yetersiz olduklarını belirlemişlerdir. Öğreten ve Sağır (2014) öğrencilerin çoğunlukla iddia ve gerekçe öğelerini kullandıklarını, çürütücü öğesini ise kullanamadıklarını tespit etmişlerdir. Tüm bunlardan hareketle, öğrencilerin karşılaştıkları bir durum için en iyi performansı iddia öne sürme bağlamında gösterdikleri, buna rağmen ortaya konan iddiaları destekleme ve çürütme hususunda yetersiz oldukları söylenebilir. Bu durum ortaya konulan bir fikri güçlendirmenin veya onun geçersiz olduğu durumları belirlemenin fikir ortaya koymaktan daha zor olmasından kaynaklanıyor olabilir. Bu durumun olası sebeplerinden bir diğeri ise, öğrencilerin farklı fikirleri sorgulayarak problem çözme bağlamında yeterli deneyim sahibi olmamaları olabilir.

Araşttrma bulgularına göre öğrencilerin ilk uygulama süresince toplam 56 argüman; ikinci uygulamada ise toplam 68 argüman ürettikleri belirlenmiştir (Tablo 11). Benzer şekilde Çetin, Kutluca ve Kaya (2013); Kuhn ve Moore (2015) öğrencilerin oluşturdukları argüman sayılarında sürecin başından sonuna doğru bir artı̧̧ olduğu sonucuna ulaşmışlardır. Duran, Doruk ve Kaplan (2017) da farklı akademik düzeydeki öğrencilerin kullandıkları argüman sayısının uygulama sürecinin sonuna doğru arttğını ifade etmiştir. Bu durumun olası sebeplerinden biri öğrencilerin sorgulayarak problem çözme bağlamında giderek daha fazla deneyim kazanmaları olabilir. Bir diğer olası sebebin de ikinci problemin birinci probleme nazaran daha fazla veri içermesi ve bu durumun öğrencileri daha fazla sorgulamaya teşvik etmesi olabileceği düşünülmektedir.

Öğrencilerin mülakatlarda, sorgulayarak problem çözme sürecinin, kendilerine bilişsel, duyuşsal, sosyal paylaşım ve dilsel bileşenler bağlamında katkı sağladığı yönünde açıklamalarda bulundukları görülmüştür Öğrenciler süreç içerisinde gerçekleştirilen sorgulamaların kendilerine farklı bilişsel deneyimler kattğı yönünde görüş belirtmişlerdir. Ayrıca uygulama sürecinin zevkli geçtiği ve arkadaşları ile birlikte olmaktan memnun olduklarını belirterek duyuşsal bileşen bağlamında söylemlere de yer vermişlerdir. Özellikle, grup içerisinde meydana gelen dayanışmanın problem çözüm 
sürecini hızlandırdığını ifade ederek de sosyal paylaşıma vurgu yapmışlardır. Çalışma grubundaki öğrencilerden Yonca ve Mehmet kendileriyle aynı seviyede bulunan öğrencilere düşüncelerini daha rahat anlatabileceklerini belirterek dilsel deneyim kapsamında görüş ifade etmiştir. Elde edilen bu bulgular Karataş (2008), Lee (2004), Vygotsky (1978) ve Yann-Shya'nın (2010) yaptıkları çalışma sonuçlarıyla tutarlılık göstermektedir. Karataş (2008) öğrencilerin problem çözme ortamları hakkında bilişsel açıdan olumlu görüşlere sahip olduğunu, tartşma sürecinde meydana gelen sosyal etkileşimler sayesinde ise ortak bir çözüm bulmak için uğraştılarını belirlemiştir. Lee (2004) öğrencilerin grup çalışması sayesinde çoklu bakış açısı imkânına sahip olduklarını, bu durumun problem çözüm sürecini olumlu yönden etkilediğini tespit etmiştir. Yann-Shya (2010) öğrencilerin birbirlerinin düşündükleri üzerinde sorgulamalar yaparak birçok fikir sunabildiğini ve dolayısıyla grup olarak çalışmanın problem çözme sürecini kolaylaştırdığını ifade etmiştir. Vygotsky (1978) ise akran dayanışmasının öğrenciler arasındaki sosyal etkileşimi geliştirdiğini, birbirine yakın bilişsel düzeylerde olan öğrencilerin birbirlerini daha rahat anlayabileceklerine vurgu yapmıştır. Belirtilenler doğrultusunda, sorgulayarak problem çözmenin öğrencilere çoklu bakış açısı sağladığı, bu durumun ve grup içinde meydana gelen dayanışmanın çözüm sürecini kolaylaştırdığı söylenebilir. Bununla birlikte, öğrencilerin birbirini daha rahat anlayabilen kişilerle aynı grupta olmaktan memnuniyet duydukları söylenebilir. Tüm bunlardan hareketle, öğretmenler öğrencileri kendi gruplarını oluşturma ve grupça sorgulayarak problem çözme bağlamlarında teşvik edebilir.

\section{5. Öneriler}

Bu araştırma matematik başarısı yüksek öğrencilerin problemler bağlamındaki argümantasyon süreçlerini incelemeye odaklanmıştır. Bununla beraber, farklı sınıf düzeylerinde veya akademik başarısı değişik seviyelerde olan öğrenciler üzerine yapılan benzer çalışmaların sayısı azdır. Bundan sonra yapılacak olan araştırmalarda bu hususlara odaklanılmasının, (ister sınıf ister akademik açıdan olsun) her seviyedeki öğrencilerin çözüm sürecinde ortaya ne tür argümanlar koyabildiklerini belirleyebilme ve bu bağlamda öğrencilere yardımcı olabilme adına önem taşıdığı düşünülmektedir. Bunlara ek olarak, öğrencilerin argümantasyon sürecinde kendilerini geliştirebilmeleri için nasıl bir öğretim ortamı tasarlanması gerektiğine yönelik araştırmalar yapılmasının da bu araştırmada elde edilen sonuçların farklı açılardan tartışılmasına olanak tanıyacağı öngörülmektedir.

\section{Kaynakça}

Akdur, T. E. ve Kurbanoğlu, H. M. (2014). Scientix Projesi: sorgulamaya dayalı fen ve matematik eğitimi. Erişim tarihi: 27 Nisan 2018, http://ab.org.tr/ab15/bildiri/129.pdf.

Akı, F. N. ve Gürel, Z. (2016). Freshman year computer engineering students' experiences for flipped physics lab class: an action research. Turkish Physical Society (s. 1- 4) içinde. Muğla: Bodrum.

Akpınar, E. ve Ergin, Ö. (2005). Yapılandırmacı kuramda fen öğretmeninin rolü. ilköğretim Online, 4 (2), 55-64.

Andriessen, J., Baker, M. J. ve Dan Suthers, D. (2003). Argumentation, computer support, and the educational context of confronting cognitions. J. Andriessen, M.J. Baker ve D. Suthers (Eds.), Arguing to learn: Confronting cognitions in computer-supported collaborative learning environments (ss.1-25) içinde. Dordrecht: Kluwer Academic Publishers.

Aymen Peker, A., Apaydın, Z. ve Taş, E., (2012). Isı yalıtımını argümantasyonla anlama: Illköğretim 6. sınıf öğrencileri ile durum çalışması. Dicle Üniversitesi Sosyal Bilimler Enstitüsü Dergisi, 4 (8), 79-100.

Brown, R. ve Redmond, T. (2007). Collective argumentation and modelling mathematics practices outsidethe classroom. Mathematics Education Research Group of Australasi (ss.163-172) içinde. Australia: University of Tasmania.

Brown, R. ve Reeves, B. (2009). Students' recollections of participating in collective argumentation when doing mathematics. Mathematics Education Research Group of Australasia (ss. 73-80) içinde. Australia: University of Massey.

Çepni, S. (2009). Araştırma ve proje çalışmalarına giriş̧ (geliştirilmiş 4.baskı). Ankara: Pegem Yayınları.

Çetin, P. S., Kutluca, A. Y. ve Kaya, E. (2014). Öğrencilerin argüman kalitelerinin incelenmesi. Fen Bilimleri Öğretimi Dergisi, 2 (1), 56-66.

Çinici, A., Özden, M., Akgün, A., Herdem, K., Karabiber, H.L. ve Deniz, Ş.M. (2014). Kavram karikatürleriyle desteklenmiş argümantasyon temelli uygulamaların etkinliğinin incelenmesi. Adıyaman Üniversitesi Sosyal Bilimler Enstitüsü Dergisi, 7(18), 571-596.

Dinçer, S. (2011). Matematik lisans derslerindeki tartışmaların Toulmin modeline göre analizi. Yayımlanmamış Doktora Tezi. Hacettepe Üniversitesi Eğitim Bilimleri Enstitüsü, Ankara.

Doruk, M. (2016). Ilköğretim matematik öğretmeni adaylarının analiz alanındaki argümantasyon ve ispat süreçlerinin incelenmesi. Yayımlanmamış Doktora Tezi, Atatürk Üniversitesi Eğitim Bilimleri Enstitüsü, Erzurum.

Driver, R., Newton, P. ve Osborne, J. (2000). Establishing the norms of scientific argumentation in classrooms. Science Education, $84(3), 287-312$.

Duran, M., Doruk, M. ve Kaplan, A. (2017). Argümantasyon tabanlı olasılık öğretiminin ortaokul öğrencilerinin başarılarına ve kaygılarına etkililiğinin incelenmesi. Eğitimde Kuram ve Uygulama, 13 (1), 55-87.

| Kastamonu Eğitim Dergisi, 27(4), 2019| 
Garcia-Mila, M. ve Andersen, C. (2008). Cognitive foundation in the study of argumentation in science classrooms. In M. Aleixandre (Ed.), Argumentation in science education: Perspectives from classroom-based research (s.29-45). NewYork: Springer.

Inglis, M., Meija-Ramos, J. P. ve Simpson, A. (2007). Modelling mathematical argumentation: the importance of qualification. Educaional Studies in Mathematics, 66 (1), 3-21.

Jimenez-Aleixandre, M., Rodriguez, R. ve Duschl, R. (2000). “Doing the lesson" or "doing science": Argument in high school genetics. Science Education, 84 (6), 757-792.

Karataş, ì. (2008). Problem çözmeye dayalı öğrenme ortamının bilişsel ve duyuşsal öğrenmeye etkisi. Yayımlanmamış Doktora Tezi, Karadeniz Teknik Üniversitesi Eğitim Bilimleri Enstitüsü, Trabzon.

Keys, C. W., Hand, B., Prain, V. ve Collins, S., (1999). Using the science writing heuristic as a tool for learning from laboratory investigations in secondary science. Journal of research in science Teaching. 36 (10), 1065-1084.

Krummheuer, G. (2007). Argumentation and participation in the primary mathematics classrom two episodes and related theoretical abductions. Journal of Mathematical Behavior, 26 (1), 60-82.

Kuhn, D. ve Moore, W. (2015). Argument as core curriculum. Learning: Research and practice, 1 (1), 66-78.

Küçük Demir, B. (2014). Argümantasyon tabanlı bilim öğrenme yaklaşımının öğrencilerin matematik başarılarına ve yaratıcı düşünme becerilerine etkisi. Yayımlanmamış Doktora Tezi. Atatürk Üniversitesi Eğitim Bilimleri Enstitüsü, Erzurum.

Lee, K. S. (2004). Effects of individual versus online collaborative case study learning strategies on critical thinking of undergraduate students. Yayımlanmamış Doktora Tezi, Teksas Üniversitesi.

Mercan, E. (2015). Fonksiyonlar konusunun öğretiminde argümantasyon tabanlı öğrenme yaklaşımının etkisinin farklı değişkenler açısından incelenmesi. Yayımlanmamış Doktora Tezi, Atatürk Üniversitesi Eğitim Bilimleri Enstitüsü, Erzurum.

Miles, M. B. ve Huberman, A.M. (1994). Qualitative data analysis : An expanded sourcebook (geliştirilmiş 2. baskı). Calif. : SAGE Publications.

Miller, M. (1987). Argumentation and cognition. In M. Hickmann (Ed.), Social and functional approaches to language and thought (s. 225-249). London: Academic Press.

Milli Eğitim Bakanlığı [MEB]. (2013). Ortaokul matematik dersi 5-8 sınıflar öğretim programı. Ankara: Milli Eğitim Bakanlığı Talim ve Terbiye Kurulu Başkanlığı, Devlet Kitapları Müdürlüğü Basım Evi.

Mueller, M. F. (2009). The co-construction of arguments by middle-school students. Journal of Mathematical Behavior, 28, $138-149$.

Mueller, M. ve Yankelewitz, D. (2014). Fallacious argumentation in student reasoning: Are there benefits?. European Journal of Science and Mathematics Education, 2 (1), 27-38.

Naylor, S. ve Keogh, B. (2007). Argumentation and primary science. Research in Science Education,37, 17-39.

Öğreten, B. ve Uluçınar Sağır, Ş. (2014). Argümantasyona dayalı fen öğretiminin etkililiğinin incelenmesi. Türk Fen Eğitimi Dergisi, 11 (1), 75-100.

Puvirajah, A. (2007). Exploring the quality and credibility of students' argumentation: teacher facilitated technology embedded scientific inquiry. Yayımlanmamış Doktora Tezi, Wayne State Üniversitesi.

Rasmussen, C., Kwon, O. N., Allen, K., Marrongelle, K. ve Burtch, M. (2006). Capitalizing on advances in mathematics and K-12 mathematics education in undergraduate mathematics: An inquiry-oriented approach differential equations. Asia Pacific Education Review, 7 (1), 85-93.

Sanchez, M. G. C. ve Uriza, R. C. (2008, Temmuz). Studying arguments in mathematics classrom: a case study. $11^{\text {th }}$ International Congress on Mathematical Education, Monterrey, Mexico.

Şekerci, A. R. (2013). Kimya laboratuvarında argümantasyon odaklı öğretim yaklaşımının öğrencilerin argümantasyon becerilerine ve kavramsal anlayışlarına etkisi. Yayımlanmamış Doktora Tezi, Atatürk Üniversitesi, Eğitim Bilimleri Enstitüsü, Erzurum.

Toulmin, S. (1958). The uses of argument. Cambridge: Cambridge University Press.

Vygotsky, L. (1998). Düşünce ve dil (S. Koray, çev.). İstanbul: Toplumsal Dönüşüm.

Yann-Shya, W. (2010). The effects of collaborative problem solving on individual problem-solving ability. National Convention of the Association for Educational Communications and Technology, 1 (2), 482-489.

Yıldırım, A. ve Şimşek, H. (2013). Sosyal bilimlerde nitel araştırma yöntemleri (geliştirilmiş 9.baskı). Ankara: Seçkin Yayınları. 


\section{EK 1: SAKSI PROBLEMI}

Mehmet Amca'nın sadece saksıda yetişen çiçekleri sattı̆ı bir dükkânı vardır. Çiçekleri müşteriler kendileri gelip alabildiği gibi, adrese teslim de yapılmaktadır. Mehmet Amca yaptı̆̆ı satı̧̧larda çiçek başına aşağıdaki fiyat tarifesini uygulamaktadır.

(Not: Her saksıda sadece bir çiçek bulunmaktadır.)

\begin{tabular}{lll}
\hline & Adrese teslim edilirse & \multicolumn{1}{c}{ Müşteri gelip alırsa } \\
\hline Müşteri saksı getirirse & $1,4 \mathrm{TL}$ & $1,5 \mathrm{TL}$ \\
Müşteri saksı getirmezse & $1,65 \mathrm{TL}$ & $1,8 \mathrm{TL}$ \\
\hline
\end{tabular}

\section{EK 2: TAKSI PROBLEMI}

İ̧ adamı olan Ahmet Bey, önemli bir toplant için o günün akşam saatinde 19.30 uçuşu ile Ankara'ya gidecektir. Havalimanına gitmeden önce şantiyeye uğramak isteyen Ahmet Bey, evinin önünden taksiye binmiştir. Ahmet Bey, taksiciye önce şantiyeye sonra da havalimanına gitmek istediğini söylemiştir. Taksici ise, taksimetre açııışını 3,5 TL ile yaptğını, 50 metreye kadar gidilen her yol ücretinin 0,25 TL olarak hesaplandığını, beklediği her dakika için 0,30 TL aldığını ve beklediği sürede taksimetreyi kapatmadığını söylemiştir. (Ahmet Bey'in evi ile şantiye arasındaki uzaklık 5 km, şantiye ile havalimanı arasındaki uzaklık 3 km'dir.)

Ahmet Bey, şantiyedeki iş için taksiyi 15 dakika bekletmiştir. Şantiyeden çıkıp taksiye bindiğinde şoföre acıktığını söylemiştir. Bunun üzerine taksici, Ahmet Bey'i bir restorana götürmüştür. Tam arabadan inecekken, Ahmet Bey o ana kadar ödeyeceği tutarın ne kadar olduğunu taksiciye sormuş ve taksici 39 TL olduğunu söylemiştir. Buna göre restoran ile şantiye arasındaki uzaklık kaç metredir? (Not: Şantiye, ev ile hava limanı arasındadır.)

\section{EK 3:YARI YAPILANDIRILMIŞ GÖRÜŞME FORMU}

- Sizce sorgulama yapmak problem çözme sürecinizi olumlu yönden ne şekilde etkiledi?

- Sizce sorgulama yapmak problem çözme sürecinizi olumsuz yönden ne şekilde etkiledi?

- Sizce sorgulama yaparak problem çözmenin kolay olan yanları nelerdir?

- Sizce sorgulama yaparak problem çözmenin zor olan yanları nelerdir?

- Süreçten ve grup arkadaşlarından memnun kaldın mı? Neden bu şekilde düşünüyorsun?

- Benzer bir tartş̧ma ortamında bulunmak ister misin? Neden bu şekilde düşünüyorsun? 